\title{
ANALISIS MINAT MAHASISWA JURUSAN IKOR MENGIKUTI KEGIATAN EKSTRAKURIKULER DI UNIMED
}

\author{
Puji Ratno
}

Surel:pujiratno@yahoo.com

\begin{abstract}
ABSTRAK
Penelitian ini bertujuan untuk menganalisis minat mahasiswa Jurusan IKOR dalam mengikuti kegiatan ekstrakurikuler di UNIMED. Metode penelitian yang digunakan adalah metode deskriptif dengan tehnik menggunakan angket dengan jumlah pernyataan sebanyak 38 butir. Sampel penelitian sebanyak 60 orang. Hasil analisis data diperoleh dari 38 pernyataan dengan 5 indikator diperoleh hasil: 1 . Pengetahuan umum terhadap kegiatan ekstrakurikuler $=$ $80,57 \%$, 2. Latar belakang mengikuti kegiatan ekstrakurikuler $=70,05 \%, 3$. Ciri-ciri kegiatan ekstrakurikuler $=77,39 \%$, 4. Faktor-faktor pemilihan kegiatan ekstrakurikuler $=71,91 \%$, 5. Motivasi mengikuti kegiatan ekatrakurikuler $=71,38 \%$. Dan minat mahasiswa Jurusan IKOR mengikuti kegiatan ekstrakurikuler di UNIMED sebesar 73,84\%. Dari data ini berarti minat mahasiswa Jurusan IKOR mengikuti kegiatan ekstrakurikuler di UNIMED termasuk dalam kategori baik.
\end{abstract}

Kata Kunci : Kegiatan Ekstrakurikuler Mahasiswa, Minat

\section{PENDAHULUAN}

Pendidikan merupakan titik sentral dalam mencerdaskan suatu bangsa, maka kemajuan pendidikan yang dijalankan banyak tergantung, bagaimana cara memberikan perlakukan yang mantap dan sesuai untuk menggali potensi para peserta didik yang mengikuti proses belajar. Salah satu usaha yang dilakukan pemerintah saat ini adalah menumbuhkan minat dan kepercayaan diri peserta didik baik untuk kegiatan formal maupun kegiatan ekstra, sehingga mereka dapat berbuat sendiri atau lebih dikenal dengan cara belajar aktif yaitu belajar sambil berpraktek.

Belajar secara aktif, mahasiswa akan lebih mudah dalam menyerap ilmu yang ia dapatkan sehingga teoriteori dapat diaplikasikan secara nyata dan bukan hanya khayalan belaka. Dalam proses belajar ada dua proses yang akan dilalui oleh peserta didik yaitu proses pemahaman dan penalaran. Oleh karena itu diharapkan dengan adanya aplikasi teori-teori pelajaran secara langsung akan lebih mempermudah siswa dalam menyerap pelajaran yang pada akhirnya tujuan belajar akan tercapai dengan baik.

Minat merupakan salah satu faktor yang mempengaruhi pencapaian prestasi. Minat bisa timbul karena daya tarik dari luar dan juga datang dari dalam diri. Minat yang besar dan kuat terhadap sesuatu hal merupakan modal yang besar dalam mencapai tujuan sebaliknya minat yang kurang cenderung menghasilkan prestasi rendah dan minat akan padam jika tidak 
disalurkan jadi harus ada suatu wadah kegiatan yang dapat menampung minat dari para peserta didik. Hasil observasi yang dilakukan peneliti di Universitas Negeri Medan terdapat 12 unit kegiatan mahasiswa (UKM) yang dapat dijadikan sarana oleh mahasiswa untuk menyalurkan minat dan bakat mereka sehingga mereka benar-benar dapat mengaktualisasikan dirinya pada salah satu unit kegiatan yang mereka sukai.

Berdasarkan realita yang ada maka penulis tertarik untuk mengetahui lebih dalam tentang minat mahasiswa IKOR untuk mengikuti kegiatan ekstrakurikuler. Karena menurut penulis, minat juga merupakan salah satu faktor penyebab mengapa mahasiswa Jurusan IKOR tidak mau mengikuti salah satu kegiatan ekstarkurikuler yang ada di UNIMED, oleh sebab itu penulis ingin meneliti minat mahasiswa Jurusan IKOR mengikuti kegiatan ekstrakurikuler di UNIMED.

Berdasarkan

pembatasan masalah yang ada, maka dirumuskanlah masalah yang akan diteliti. Adapun rumusan masalahnya adalah, bagaiaman minat mahasiswa Jurusan IKOR mengikuti kegiatan ekstrakurikuler di UNIMED.

\section{METODE PENELITIAN}

Dalam

melakukan

penelitian penulis menggunakan tehnik pengumpulan data dengan metode deskriptif dengan tehnik analisis menggunakan angket.
Sampel adalah sebagai dari populasi atau yang mewakili populasi yang diteliti, mengingat populasi penelitian ini besar dengan jumlah 200 orang, maka dilakukan penarikan atau pengambilan samel sebagai responden untuk diteliti. Dalam penelitian ini penulis mengambil $30 \%$ dari populasi untu dijadikan sampel yaitu dengan jumlah 60 orang. Pengambilan sampel dilakukan oleh penulis adalah dengan tehnik random sampling atau sampel acak.

\section{HASIL DAN PEMBAHASAN}

Setelah melaksakan penelitian yaitu menyebarkan angket tentang minat mahasiswa jurusan IKOR mengikuti kegiatan ekstrakurikuler di UNIMED, diperoleh data-data. Dari data yang telah terkompul, langkah selanjutnya adalah mendeskripsikan data dengan menghitung persentase dari angket yang diperoleh, kemudian disesuaikan dengan kategori yang telah ditentukan. Dari hasil penyebaran angket, telah diperoleh data dan selanjutnya diakumulasi menjadi data seharusnya, kemudian data yang telah diakumulasi tersebut dimasukkan kedalam daftar tabel. Dibawah ini akan diuraikan hasil penyebaran angket setelah diakumulasi:

1. Pengetahuan umum terhadap kegiatan ekstrakurikuler, diperoleh data dengan menjawab option SS=144 dengan skor 576, $\mathrm{S}=300$ dengan skor $900, \mathrm{KS}=35$ dengan skor 70 , dan $\mathrm{SKS}=1$ 
dengan skor 1, dengan jumlah keseluruhan data mentah $=1547$, seharusnya $=1920$.

2. Latar be;akang mengikuti kegiatan ekstrakurikuler , diperoleh data dengan menjawab option SS=89 dengan skor 356, $\mathrm{S}=187$ dengan skor $561, \mathrm{KS}=126$ dengan skor $252, \mathrm{SKS}=8$ dengan skor $8, \quad$ dengan jumlah keseluruhan data mentah $=1177$, seharusnya 1680.

3. Cirri-ciri kegiatan ekstrakurikuler, diperoleh data dengan menjawab option $\mathrm{SS}=$ dengan skor $152, \mathrm{~S}=$ 124 dengan skor $372, \mathrm{KS}=61$ dengan skor 122, dan $\mathrm{SKS}=17$ dengan skor 17 , dengan jumlah keseluruhan data mentah $=743$, seharusnya 960.

4. Factor-faktor pemilihan kegaitan ekstrakuruikuler diperoleh data dengan menjawab option $\mathrm{SS}=110$ dengan skor $440, S=335$ dengan skor $1005, \mathrm{KS}=133$ dengan skor 266, SKS $=15$ dengan skor 15 , dengan jumlah data mentah = 1726, seharusnya 2400.

5. Motivasi mengikuti kegaitan ekstrakurikuler, diperoleh data dengan menjawab option $\mathrm{SS}=90$ dengan skor 360, $\mathrm{S}=301$ dengan skor $903, \mathrm{KS}=126$ dengan skor 252, SKS=27 dengan skor 27, dengan deseluruhan data mentah $=1542$, seharusnya 2160 .

Frekuensi dan Skor Minat Mahasiswa Jurusan IKOR

Mengikuti Kegiatan Ekstrakurikuler

\begin{tabular}{|c|c|c|c|c|c|c|c|c|c|}
\hline \multirow{3}{*}{ No } & \multirow{3}{*}{ Item } & \multicolumn{8}{|c|}{ OPTION } \\
\hline & & \multicolumn{2}{|c|}{ SS } & \multicolumn{2}{|c|}{$\mathbf{S}$} & \multicolumn{2}{|c|}{ KS } & \multicolumn{2}{|c|}{ SKS } \\
\hline & & $\mathbf{J}$ & $\mathbf{S}$ & $\mathbf{J}$ & $\mathbf{S}$ & $\mathbf{J}$ & $\mathbf{S}$ & $\mathbf{J}$ & $\mathbf{S}$ \\
\hline 1 & $\begin{array}{l}\text { Pengetahuan } \\
\text { umum terhadap } \\
\text { kegiatan } \\
\text { ekstrakurikuler }\end{array}$ & $\begin{array}{l}1 \\
4 \\
4\end{array}$ & $\begin{array}{l}5 \\
7 \\
6\end{array}$ & $\begin{array}{l}3 \\
0 \\
0\end{array}$ & $\begin{array}{l}9 \\
0 \\
0\end{array}$ & $\begin{array}{l}3 \\
5\end{array}$ & $\begin{array}{l}7 \\
0\end{array}$ & 1 & 1 \\
\hline 2 & $\begin{array}{l}\text { Latar belakang } \\
\text { mengikuti kegiatan } \\
\text { ekstrakurikuler }\end{array}$ & $\begin{array}{l}8 \\
9\end{array}$ & $\begin{array}{l}3 \\
5 \\
6\end{array}$ & $\begin{array}{l}1 \\
8 \\
7\end{array}$ & $\begin{array}{l}5 \\
6 \\
1\end{array}$ & $\begin{array}{l}1 \\
2 \\
6\end{array}$ & $\begin{array}{l}2 \\
5 \\
2\end{array}$ & 8 & 8 \\
\hline 3 & $\begin{array}{l}\text { Ciri-ciri kegiatan } \\
\text { ekstrakurikuler }\end{array}$ & $\begin{array}{l}3 \\
8\end{array}$ & $\begin{array}{l}1 \\
5 \\
2\end{array}$ & $\begin{array}{l}2 \\
4\end{array}$ & $\begin{array}{l}1 \\
7 \\
2\end{array}$ & $\begin{array}{l}6 \\
1\end{array}$ & $\begin{array}{l}1 \\
2 \\
2\end{array}$ & 17 & 17 \\
\hline 4 & $\begin{array}{l}\text { Factor-faktor } \\
\text { pemilihan kegaitan } \\
\text { ekstrakurikuler }\end{array}$ & $\begin{array}{l}1 \\
1 \\
0\end{array}$ & $\begin{array}{l}4 \\
4 \\
0\end{array}$ & $\begin{array}{l}3 \\
3 \\
5\end{array}$ & $\begin{array}{l}1 \\
0 \\
0 \\
5\end{array}$ & $\begin{array}{l}1 \\
3 \\
3\end{array}$ & $\begin{array}{l}2 \\
6 \\
6\end{array}$ & 15 & 15 \\
\hline
\end{tabular}




\begin{tabular}{|c|c|c|c|c|c|c|c|c|c|}
\hline 5 & $\begin{array}{l}\text { Motivasi } \\
\text { mengikuti kegiatan } \\
\text { ekstrakurikuler }\end{array}$ & $\begin{array}{l}9 \\
0\end{array}$ & $\begin{array}{l}3 \\
6 \\
0\end{array}$ & $\begin{array}{l}3 \\
0 \\
1\end{array}$ & $\begin{array}{l}9 \\
0 \\
3\end{array}$ & $\begin{array}{l}1 \\
2 \\
6\end{array}$ & $\begin{array}{l}2 \\
5 \\
2\end{array}$ & 27 & 27 \\
\hline & Jumlah & $\begin{array}{l}4 \\
9 \\
1\end{array}$ & $\begin{array}{l}1 \\
9 \\
6 \\
4\end{array}$ & $\begin{array}{l}1 \\
2 \\
4 \\
7\end{array}$ & $\begin{array}{l}3 \\
7 \\
4 \\
1\end{array}$ & $\begin{array}{l}4 \\
8 \\
1\end{array}$ & $\begin{array}{l}9 \\
6 \\
2\end{array}$ & 68 & 68 \\
\hline
\end{tabular}

Keterangan:

$\mathrm{J}$ : Jumlah yang menjawab option

SS, S, KS, dan SKS,

S: Skor dari jumlah option tersebut.

Persentase dan Rekapulasi Data Keseluruhan Minat Mahasiswa Mengikuti Kegiatan Ekstrakurikuler

\begin{tabular}{|c|c|c|c|c|c|}
\hline \multirow{2}{*}{ No } & \multirow{2}{*}{ Indikator } & \multicolumn{4}{|c|}{ Skor } \\
\hline & & Mentah & Seharusnya & $\%$ & Persentase \\
\hline 1 & $\begin{array}{lr}\text { Pengetahuan } & \text { umum } \\
\text { terhadap } & \text { kegiatan } \\
\text { ekstrakurikuler } & \\
\end{array}$ & 1574 & 1920 & 100 & $80,57 \%$ \\
\hline 2 & $\begin{array}{l}\text { Latar belakang mengikuti } \\
\text { kegiatan ekstrakurikuler }\end{array}$ & 1177 & 1680 & 100 & $70,05 \%$ \\
\hline 3 & $\begin{array}{ll}\text { Ciri-ciri } & \text { kegiatan } \\
\text { ekstrakurikuler } & \end{array}$ & 743 & 960 & 100 & $71,91 \%$ \\
\hline 4 & $\begin{array}{l}\text { Faktor-faktor pemilihan } \\
\text { kegiatan ekstrakurikuler }\end{array}$ & 1726 & 2400 & 100 & $71,38 \%$ \\
\hline 5 & $\begin{array}{l}\text { Motivasi mengikuti } \\
\text { kegiatan ekstrakurikuler }\end{array}$ & 1542 & 2160 & 100 & $71,38 \%$ \\
\hline & Jumlah & 6735 & 9120 & 100 & $73,84 \%$ \\
\hline
\end{tabular}

Pembahasan Hasil Penelitian

Berdasarkan hasil penelitian tentang minat mahasiswa jurusan IKOR mengikuti kegiatan ekstrakurikuler di UNIMED, didapatkan dta yang berasal dari angket tentang minat mahasiswa jurusan IKOR mengikuti kegiatan ekstrakurikler di UNIMED. Angket yang disebarkan ke dalam 5 indikator, dengan 60 orang nilai persentase keseluruhan sebagai sampel, dan kemudian penulis mendapatkan data dengan nilai persentase keseluruhan sebesar $73,84 \%$, yang masuk de dalam kategori baik. Berikut ini akan di bahas data yang diperoleh dari 5 indikator angket yang telah berhasil di kumpulkan oleh penulis tentang 
minat mahasiswa jurusan IKOR mengikuti kegiatan ekstrakurikuler di UNIMED.

1. Pengetahuan umum terhadap kegiatan ekstrakurikuler memperoleh nilai persentase keseluruhan sebesar $80,57 \%$ yang termasuk kategori sangat baik. Hal ini didapatkan dari pernyataan dari nomor $1,2,3,4,5,30,31$, dan 38 , tentang keberadaan, tujuanm dam manfaat dari kegiatan ekstrakurikuler yang ada di UNIMED. Dari 60 responden yang menjawab sangat setuju (SS) sebanyak 30\%, setuju (S) sebanyak 62,50 \%, kurang setuju (KS) 7,29\%, dan menjawab sangat kurang setuju (SKS) $0,002 \%$. Dari persentase di atas maka dapatlah kita ketahui hampir seluruh responden mengetahui dan setuju tentang keberadaan, tujuan, dan manfaat dari kegiatan ekstrakurikuler yang ada di UNIMED. Tingginya pengetahuan mahasiswa tentang kegiatan ekstrakurikuler di UNIMED, dimungkinkan karena kerja keras masing-masing pengurus setiap unit-unit kegiatan ekstrakurikuler yang lebih dikenal dengan UKM (Unit Kegiatan Mahasiswa) untuk mensosialisasikan UKM masingmasing melalui penyebaran brosur-brosur, persentase tentang tujuan dan manfaat dari setiap UKM, mengisi acara pada saat penyambutan mahasisiwa baru yang diadakan setiap tahun ajaran baru, melakukan atraksi atau menunjukkan keterampilan yang ada pada masing-masing UKM. Dengan adanya penyebaran brosur, persentase tentang tujuan dan manfaat dari setiap UKM, serta atraksi yang ditunjukkan pada saat penyambutan mahasiswa baru, makalah inilah yang mungkin menyebabkan mengapa pengetahuan umum tentang kegiatan ekstrakurikuler di UNIMED tergolongan ke dalam kategori sangat baik.

2. Latar belakang mengikuti kegiatan ekstrakurikuler, memperoleh inilah persentase keseluruhan sebesar 70,05\% yang termasuk ke dalam kategori baik. Hal ini didapat dari pernyataan nomor $\quad 6,7,8,9,10,34$,dan 37 , tentang latar belakang mengikuti kegiatan ekstrakurikuler, apakah atas keinginan sendiri, karena ingin mengasah bakatnya, karena mata kuliah yang ia ambil pada saat perkuliahan, karena ingin mencari kesenangan, kerana jam perkuliahan tidak padat, dan ingin meningkatkan kondisi fisik. Untuk indicator ini responden yang menjawab sangat setuju (SS) sebanyak $21,19 \%$ setuju (S) sebanyak 44,52\%, kurang setuju (KS) sebanyak 30,0\%, dan sangat kurang setuju (SKS) sebanyak $1,90 \%$. Responden yang menyatakan sangat setuju dan setuju sebesar $65,71 \%$, hal ini mungkin karena seorang 
mahasiswa sadar bahwa dengan mengikuti kegiatan ekstrakurikuler ia akan mendapatkan keterampilan dan pengetahuan yang luas, dan sadar bahwa dalam dirinya telah ada bakat yang terpendam, dan bakatnnya tersebut harus disalurkan melalui salah satu kegiatan ekstrakurikuler, dan mungkin juga karena jam perkuliahannya tidak padat, dan ia mempunyai waktu luang untuk mengikuti kegiatan eksttrakurikuler, sehinggan ia mengikuti ekstrakurikuler sesuai dengan mara kuliah yang diambil pada saat perkuliahan. Contoh pada saat mata kuliah basket maka ia mengikuti kegiatan ekstrakurikuler karena ingin meningkatkan kondisi fisiknya hal ini bisa terjadi karena di UNIMED dan UKM yang dapat melatih dan meningkatkan kondisi fisik, yaitu UKM tarung derajat, selain dapat meningkatkan kondisi fisik, UKM tarung derajat juga memberikan keterampilan bela diri kepada setiap anggota. Hal-hal inilah yang melatar belakangi mengapa mahasiswa mengikuti kegiatan ekstrakurikuler di UNIMED. Sebanyak 32,90\% menyatakan kurang setuju dan sangat kurang setuju. Hal ini mungkin disebabkan mereka tidak mengetahui secara jelas manfaat dari kegiatan ekstrakurikuler, sehingga tidak menimbulkan kesadaran dalam diri mereka untuk mengikuti kegiatan ekstrakurikuler. Kemudian mereka mempunyai jam perkuliahan yang padat, hal ini sering terjadi pada mahasiswa semester awal, dimana jam perkuliahan dimulai pada pagi hari sampai sore hari. Oleh karena jam perkuliahan yangt terlalu padat maka mahasiswa tidak ada waktu untuk mengikuti kegiatan ekstrakurikuler.

3. Ciri-ciri kegiatan ekstrakurikuler, memperoleh persentase nilai secara keseluruhan sebesar $77,39 \%$ yang termasuk dalam kategori baik. Hal ini dapat dilihat dari data pernyataan nomor 11 , 12,13, dan 14, tentang apakah kegiatan ekstrakurikuler diwajibkan di fakulatas, kegiatannya terorganisir dengan baik, kegiatannya diprogramkan menyenangkan, dan kegiatan yang dapat menimbulkan kreatifitas serta gairah belajar. Untuk indicator ini mahasiswa yang menjawab sangat setuju (SS) sebanyak 15,83\%, setuju (S) sebanyak 51,66\%, kurang setuju (KS) sebanyak $25.49 \%$ dan sangat kurang setuju (SKS) sebanyak $7,08 \%$. Dari data ini dapat diketahui bahwa 67,49 mahasiswa mengetahui cirri-ciri kegiatan ekstrakurikuler denga baik, hal ini mengkin disebabkan oleh teraksananya kegiatan-kegiatan setiap UKM dengan baik, hal ini disebabkan oleh terorganisir suatu 
kegiatan dengan baik, sehingga kegiatan-kegiatan yang mereka laksanakan dapat terlaksana dengan baik, dan biasanya kegiatan-kegiatan yang mereka melaksakan adalah yang menyenangnkan. Untuk merencanakan dan melaksanakan suatu kegiatan yang baik dan menyenangkan tentunya membutuhkan kreatifitaskreatifitas baru, sehingga kegiatan yang dirancang berbeda dari kegiatan-kegiatan yang diadakan sebelumnya. Hal ini yang akan membuat orang akan tertarik untuk mengikuti kegiatan tersebut. Dari hal-hal inilah mahasiswa menilai bahwa suatu kegiatan ekstrakurikuler haruslah terorganisir dengan baik, kegiatannya menyenangkan, dan untuk menghasilakan suatu kegiatan yang baik dan menyenangkan, maka diperlukanlah kreatifitas yang tinggi. Hal-hal inilah yang menyebabkan mengapa mahaiswa mengetahui dengan baik cirri-ciri dari kegiatan ekstrakurikuler.

4. Faktor-faktor pemilihan kegiatan ekstrakurikuler memperoleh nilai persentase secara keseluruhan sebesar $71,91 \%$ yang termasuk dalam kategori baik. Hal ini dapat dilihat dari pernyataan nomor $15,16,17,18,19,20,21,26,23$,dan 36 tentang factor-faktor apa saja yang membuat mereka mengikuti kegiatan ekstrakurikuler, apakah karena kewajiban mata kuliah, karena ingin berprestasi, karena ingin mengasah bakatnya, dan senang melihat kegiatan ekstrakurikuler. Dari data yang telah diperoleh yang menjawab sangat setuju (SS) sebanyak 18,33, setuju (S) sebanyak $55,83 \%$, kurang setuju (KS) sebanyak $74,16 \%$ responden memilih kegiatan ekstrakuriuler kerena kewajiban dari mata kuliah, ingin berprestasi, ingin mengasah bakatnya, dan senang melihat ekstrakurikuler. Hal ini mungkin disebabkan oleh tuntutan dari dosen mata kuliah yang menginginkan mahasiswa mempunyai pengetahuan, keterampilan dan dapat menyalurkan bakatnya melaui kegiatan ekstrakurikuler. Ketika mahasiswa mengikuti kegiatan ekstrakurikuler ia mendapatkan keterampilan dan ia juga dapat berprestasi dengan mengikuti kegiatan yang diwajibkan oleh dosen dari mata kuliah. Contohnya ketika mahasiswa mengikuti mata kuliah pencak silat, maka dosen akan mewajibkan mahasiswa untuk mengikuti ekstrakurikuler pencak silat, dan dapat maraih prestasi diberbagai kejuaraan pencak silat yang ia ikuti. Factor-faktor inilah yang menyebabkan mahasiswa memilih kegiatan ektrakurikuler di UNIMED.

5. Motivsi mengikuti kegiatan ekstrakurikuler memperoleh nilai persentase keseluruhan sebesar 
$71,38 \%$ yang termasuk ke dalam kategori baik. Data ini didapat dari pernyataan nomor $22,23,24$, $25,27,28,29,32$, dan 35, tentang apakah mahasiswa mempunyai waktu luang, karena kinginan dari orang tua, karena kondisi kesehatan, dan karena ajakan teman. Dari data yang diperoleh responden yang menjawab sangat setuju (SS) sebanyak 16,66\%, setuju (S) sebanyak 55,74\%, kurang setuju (KS) sebanyak 23,33\% dan sangat kurang setuju (SKS) sebanyak 5,0\%. Sebanyak $72,4 \%$ responden menyatakan sangat setuju dan setuju, mereka termotivasi mengikuti kegiatan ekstrakurikuler karena adanya waktu luang, keinginan dari orangtua, kondisi kesehatan, ajakan dari teman. Hal ini mungkin terjadi karena mereka mempunyai waktu luang yang dapat mereka isi dengan mengikuti kegiatan ekstrakurikuler. Mungkin karena kinginan dari orang tua, yang mengetahui bahwa dengan mengikuti kegiatan ekstrakurikuler anaknya akan memperoleh keterampilan, dapat belajar disiplin, mandiri, dan kreatif. Apalagi orang tuanya melihat bahwa anaknya memiliki waktu luang. Mungkin juga karena teman sepermainannya, teman sekampusnya, teman sekelasnya, banyak yang mengikuti ekstrakurikuler, sehingga mungkin ia diajak untuk melihat-lihat saja, yang kemudian timbul rasa untuk mencoba bergabung dengan temantemannya tersebut. Dengan adanya keinginan dari orang tua, waktu luang dan ajakn dari teman mak banyak mahasiswa yang termotivasi untuk mengikuti kegiatan ekstrakurikuler di UNIMED. Hal-hal ini yang menyebabkan mahasiswa mengikuti kegiatan ekstrakurikuler di UNIMED.

Berdasarkan dari hasil pembahasan dari 5 indikator tentang minat mahasiswa jurusan IKOR mengikuti kegiatan ekstrakurikuler di UNIMED, ternyata minat mahasiswa jurusan IKOR mengikuti kegiatan ekstrakurikuler di UNIMED, masuk ke dalam kategori baik dengan persentase keseluruhan sebesar 73,84\%. Hal ini dikarenakan pengetahuan umum mahasiswa tentang kegiatan ekstrakurikuler di UNIMED termasuk dalam kategori baik, yang ditandai dengan banyaknya mahasiswa yang mengetahui keberadaan, tujuan, dan manfaat dari kegiatan ekstrakurikuler, yang informasi itu mereka peroleh dari brosur-brosur yang disebarkan oleh setiap pengurus UKM, persentase setiap UKM, dan antraksi atau pertunjukkan yang selalu diperlihatkan kepada setiap mahasiswa pada setiap penyambutan mahasiswa baru, dengan persentase mahasiswa yang sangat ssetuju dan setuju sebesar $92,50 \%$. latar belakang mahasiswa mengikuti 
kegiatan ekstrakurikuler masuk ke dalam kategori baik, dengan persentase mahasiswa yang sangat setuju dan setuju sebesar $65,71 \%$, hal ini mungkin disebabkan oleh kesadaran mahasiswa, atas penting mengikuti kegiatan ekstrakurikuler, sehingga dengan sendirinya mereka mengikuti kegiatan ekstrakurikuler, mereka berharap dapat menyalurkan bakatnya, ingin menambah pengetahuan dan kemampuan melalui kegiatan ekstrakurikuler yang mereka ikuti. Cirri-ciri kegiatan ekstrakurikuler masuk kedalam kategori baik, dengan persentase mahasiswa yang menyatakan sangat setuju dan setuju sebesar 76, 49\%, hal ini mungkin disebabkan oleh adanya cirri-ciri yang jelas tentang kegiatan ekstrakurikuler, yaitu kegiatan terorganisir dengan baik, kegiatan menyenangkan, dan dapat menimbulkan gairah dan semangat belajar. Factor-faktor pemilihan kegiatan ekstrakurikuler masuk ke dalam kategori baik, dengan persentase mahasiswa yang menyatakan sangat setuju dan setuju sebesar $74,16 \%$, hal ini mungkin disebabkan oleh banyak mahasiswa yang ingin mengasah bakat dan ingin mempunyai prestasi melalui kegiatan ekstrakurikuler. Hal ini mungkin terjadi karena setiap UKM yang ada di UNIMED memberikan kesempatan dan peluang kepada setiap anggotanya untuk mengembangkan bakat dan kemampuannya serta berprestasi yang tinggi. Motivasi mengikuti kegiatan ekstrakurikuler masuk ke dalam kategori baik dengan $72,40 \%$, hal ini mungkin disebabkan oleh karena adanya waktu luang, adanya keinginan dari orang tua dan ajakan dari teman-temannya, sehingga dengan adanya motivasimotivasi tersebut di atas banyak mahasiswa yang mengikuti kegiatan ekstrakurikuler di UNIMED.

\section{KESIMPULAN}

Berdasarkan dari hasil analisis data terhadap lima indikator tentang minat mahasiswa Jurusan IKOR mengikuti kegiatan ekstrakurikuler, yang telah dilakukan, didapat data yaitu:

1. Pengetahuan umum tentang kegiatan ekstrakurikuler memperoleh nilai sebesar $80,57 \%$ yang termasuk dalam kategori sangat baik.

2. Latar belakang kegiatan ekstrakurikuler, memperoleh nilai sebesar $70,05 \%$, yang termasuk dalam kategori baik.

3. Ciri-ciri kegiatan ekstrakurikuler, memperoleh nilai sebesar $77,39 \%$, yang termasuk dalam kategori baik.

4. Faktor-faktor pemilihan kegiatan ekstrakurikuler, memperoleh nilai sebesar $71,91 \%$, yang termasuk dalam kategori baik.

5. Motivasi mengikuti kegiatan ekstrakurikuler, memperoleh nilai sebesar 71,38\%. Dan dapat disimpulkan bahwa minat mahasiswa jurusan IKOR dalam mengikuti kegiatan ekstrakurikuler berada dalam 
kategori baik, yaitu dengan persetase $73,84 \%$. Hal ini disebabkan kerena mereka dapat mengembangkan bakat yang mereka miliki, menambah pengetahuan dan wawasan mereka, serta mereka ingin mencapai pretasi tertentu melalui kegiatan ekstrakurikuler.

Setelah melakukan analisis terhadap minat mahasiswa jurusan IKOR, adapun saran dari peneliti yaitu:

1. Kepada mahasiswa Jurusan IKOR yang mengikuti kegiatan ekstrakurikuler di UNIMED hendaknya dapat mengembangkannya di masyarakat luas.

2. Bagi mahasiswa Jurusan IKOR yang belum mengikuti hendaknya dapat mengikuti salah satu kegiatan ekstrakurikuler yang ada.

3. Kepada para pengurus kegiatan ekstrakurikuler yang ada, agar dapat merencakan programprogram yang baik lagi, unruk menarik minat mahasiswa mengikuti kegiatan ekstrakurikuler.

4. Bagi para dosen agar dapat memotivasi para mahasiswa untuk mengikuti kegiatan ekstrakurikuler.

\section{DAFTAR RUJUKAN}

Arikunto, Suharsimi. (2002). Prosedur Penelitian. Jakarta: PT. Rineka Cipta.
Fakultas Ilmu Keolahragaan. (2004).

Rencana Strategi

(RENSTRA) Tahun 2005-

2010 dan rencana kerja

(RKT) Tahun 2005. Medan.

Gunarsa, C. Singgih. (2000). Psikologi Praktis Anak Remaja, dan Keluarga. Jakarta: BPK Gunung Mulia.

Kantor Pembantu Rektor III. (2005). Data Unit Kegiatan Mahasiswa UNIMED. Medan.

Lasarati. (2005). Hubungan antara Kreatifan Dalam Mengikuti Kegiatan Ekstrakuriluler Dengan Motivasi Belajar Pada Siswa SMA Negeri 2 Medan. (Skripsi), tidak terbitkan. Medan: Fakultas Ilmu UMA.

Muhibbin, Syah. (2003). Psikologi Pendidikan Dengan Pendekatan Baru. Jakarta: PT. Remaja Rosada Karya.

Prastito, Arif. (2005). Cara Mudah Mengikuti Masalah Statistik dan Rancangan Percobaan Dengan SPSS 12. Jakarta: PT. Elex Media Komputindo.

Sarwono, S. Wirawan. (2000). Psikologi Remaja. Jakarta: PT. Remaja.

Slameto. (2003). Belajar Dan Faktorfaktor yang Mempengaruhinnya. Jakarta: PT. Rineka Cipta.

Sudjana. 1988. Metode Statistika. Bandung: Tarsito. 
Puji Ratno: Analisi Minat Mahasiswa ..

Surahman, Wnarno. (1982). Vera. (2005). Penguatan Membaca, Pengantar Penelitian Ilmiah. Bandung: Tarsito.

Tim Penyusun Kamus Pusat Pembinaan dan Pengembangan Bahasa. (1986). Kamus Besar Indonesia. Jakarta: Balai Fasilitas Lingkungan Sekolah dan Keterampilan Dasar Bahasa Indonesia, Serta Minat Baca Murid. http:/www I.bpk penabur. Or.id/jurnal/04/017-035.pdf. Jakarta.

Pustaka. 